\title{
THE TERritory PARADOX: THE BASIS OF STATEHOOD AND INTERNATIONAL NORMS AS AN ObSTACLE TO THE PROTECTION OF INTERNATIONAL COMMUNITY INTERESTS
}

\author{
NICOLÁS CARRILLO-SANTARELLI*
}

\begin{abstract}
INTRODUCTION
Some say that we live in a post-national world, in which affiliations are not solely or even primarily based on identities founded on nationality but rather on ideological, religious, and even economic considerations, sometimes related to transnational actors such as religious groups or multinational structures. ${ }^{1}$ Furthermore, the global social landscape challenges States in different ways. Among other things, States face challenges of actors as varied as transnational corporations, drug cartels, or terrorist and rebel groups, many of which have something that States do not: territorial and political flexibility. Indeed, many non-state actors focus on narrower issues while States have a myriad of responsibilities, and are also freer to pursue their aims across borders, ignoring territorial constraints, while States and their power are still largely determined by the territories they exert jurisdiction over. ${ }^{2}$ To this, it must be added that non-state actors sometimes have considerable power that rivals even the power of some States. We can think, among others, of some transnational corporations and multinational groups whose economic resources surpass those of developing countries, or

DOI: $10.1515 /$ wrlae-2018-0021

* PhD, Professor of International Law, La Sabana University (Colombia); nicolas.carrillos@gmail.com; ORCID: https://orcid.org/0000-0001-7053-118X.

${ }^{1}$ Alfred Van Staden and Hans Vollaard, 'The Erosion of State Sovereignty: Towards a Postterritorial World?' in Gerard Kreijen et al (eds), State, Sovereignty, and International Governance (OUP 2002) 167-168.

${ }^{2}$ Daniel Thürer, 'The Emergence of Non-Governmental Organizations and Transnational Enterprises in International Law and the Changing Role of the State' in Rainer Hofmann (ed), Non-State Actors as New Subjects of International Law (Duncker \& Humblot 1999) 40, 47, 58; Rafael Domingo, The New Global Law (CUP 2010) 63.
\end{abstract}


armed and criminal groups that are able to fight against States, sometimes even controlling part of their territories. ${ }^{3}$

In spite of the previous considerations, international law is still largely shaped by States and reflects a State-centric conception in some of its core elements, such as law-making and responsibility. The responsibility of other subjects, which is necessary to protect legal goods as those embodied in human rights, ${ }^{4}$ is still debated and challenged by many, as reflected by discussions on a treaty on business and human rights; ${ }^{5}$ and while international organizations and some actors have some input in the formation of custom and other sources, States still largely control them. ${ }^{6}$ Truly, some regimes as human rights ones rightly focus on individuals, but most of the time these individuals can claim only against States from a procedural point of view. Some may consider that the current focus on States, which are territorial entities, prevents international law from properly addressing the challenges of a global world, which to my mind is an appropriate criticism. This explains the emergence of theories such as Global Administrative Law and focus on the global rule of law considerations. ${ }^{7}$ For better or worse, international law is dominated to a great extent by State-centric legal criteria.

This being so, and States having important prerogatives, it is not surprising that many aspirations and tensions nowadays pivot around Statehood and dominion over territories, especially given the expressive or symbolic attractiveness of independence for many. The claims of the Kurds, the plight of Ukraine and aspirations of secession by some Catalonians, Scots and others confirm that even in a globalized world independent Statehood is

\footnotetext{
${ }^{3}$ Celestino del Arenal, 'La nueva sociedad mundial y las nuevas realidades internacionales: un reto para la teoría y para la política' in Cursos de Derecho Internacional y Relaciones Internacionales de Vitoria-Gasteiz 2001 (EHU 2002); Francisco Galindo Vélez, 'Consideraciones sobre la determinación de la condición de refugiado' in Sandra Namihas (ed), Derecho Internacional de los Refugiados (Pontificia Universidad Católica del Perú 2001) 125-126; Alexandra Gatto, 'Corporate Social Responsibility in the External Relations of the EU' (2005) 24 Yearbook of European Law 423; Protocol Additional to the Geneva Conventions of 12 August 1949, and relating to the Protection of Victims of NonInternational Armed Conflicts (Protocol II), art 1.

${ }^{4}$ Nicolás Carrillo-Santarelli, 'Enhanced Multi--Level Protection of Human Dignity in a Globalized Context through Humanitarian Global Legal Goods' (2012) 13 German Law Journal 829-873.

${ }^{5}$ Human Rights Council, Report on the first session of the open-ended intergovernmental working group on transnational corporations and other business enterprises with respect to human rights, with the mandate of elaborating an international legally binding instrument [2016] A/HRC/31/50; Surya Deva and David Bilchitz, 'Response to Comments of Professor John Ruggie on "Human Rights Obligations of Business: Beyond the Corporate Responsibility to Respect?" (CUP 2013)' (15 January 2014) < $\underline{\text { http://business- }}$ humanrights.org/sites/default/files/media/documents/surya-deva-david-bilchitz-re-ruggie15-01-14.pdf> accessed 19 May 2016.

${ }^{6}$ Jean-Marie Henckaerts, 'Customary International Humanitarian Law: a response to US comments' (2007) 89 Intl Rev of the Red Cross 473, 478-479; Jean d'Aspremont, 'Non-State Actors in International Law: A Scholarly Invention?' (2009) FWO Seminar - Non-State Actors in International Law - Leuven 26-28 March 2009 1, 2, 5-6; International Law Commission, Identification of customary international law: Text of the draft conclusions provisionally adopted by the Drafting Committee [2015] A/CN.4/L.869, Draft conclusion 4 [5].

${ }^{7}$ Jan Klabbers, International Law (CUP 2013) 306, 316-317.
} 


\section{STATEHOOD AND INTERNATIONAL NORMS AS AN \\ OBSTACLE TO THE PROTECTION OF INTERNATIONAL COMMUNITY INTERESTS}

attractive, both for the power it confers and for political reasons. Furthermore, some States fiercely cling to territorial unity, as China reveals, or favour a centralistic model, such as the French one.

Curiously, State-centrism is not only at odds with many social realities and needs. The persistent international relevance of Statehood and its legal treatment, far from providing stability, creates tension. This is because of the fact that the criterion of effective (territorial) control is often decisive when determining if there is a successful secession or to continued territorial integrity. As a consequence, both those actors who seek independence and those that desire to keep territorial unity are encouraged, by legal gaps and lack of detailed rules on independence, to assert dominion from a factual point of view, given its legal implications. Thus, the legal effects attached to effective control generate a paradox, because while international law nominally favours stability it actually encourages instability in some cases.

But that is not the only paradox. While States are territorial creatures, the borders of which are historical constructions and unpredictable, their political (and ethical) goals sometimes prompt them to operate extraterritorially. This creates tensions and problems, given the potential overlap between different States. This is due to the fact that, except for a few international spaces such as the high seas or Antarctica or outer space, ${ }^{8}$ world territories are divided up between States. For instance: what happens when a State exercises executive (not judicial or legislative) jurisdiction abroad, detaining someone and the male captus, bene detentus maxim is invoked? ${ }^{9}$ What happens when States try to defend themselves or their population from armed groups located in a foreign territory whose State is unwilling or unable to deal with such groups? Should States have an extraterritorial obligation to protect victims from abusive transnational businesses linked to them when the State in which they operate diligently strives to prevent or respond to their abuses but is unable to do so? These and other problems are generated by the fact that international law still largely reflects a State and territorial system which may have become partly outdated, as Domingo-Oslé has pointed out. ${ }^{10}$ As a reaction to these problems and tensions, some international legal developments and projects aim to protect community interests ${ }^{11}$ across, or ignoring, borders, thus permitting exercises of universal jurisdiction, transnational litigation or other actions in which State and other agents

\footnotetext{
${ }^{8}$ Gbenga Oduntan, Sovereignty and Jurisdiction in the Airspace and Outer Space: Legal Criteria for Spatial Delimitation (Routledge 2012) 132; John Kish, International Law and Espionage (Martinus Nijhoff 1995) 102.

${ }^{9}$ Christian Henderson, 'The Extraterritorial Seizure of Individuals under International Law - The Case of al-Liby: Part II' (EJIL: Talk!, 7 November 2013) <http://www.ejiltalk.org/theextraterritorial-seizure-of-individuals-under-international-law-the-case-of-al-liby-part-

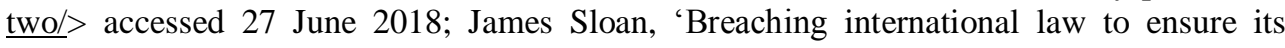
enforcement: the reliance by the ICTY on illegal capture' (2003) 6 Yearbook of International Humanitarian Law 319, 325-328.

${ }^{10}$ Domingo (n 2) 61-64, 85-86, 114.

${ }^{11}$ Santiago Villalpando, 'The Legal Dimension of the International Community: How Community Interests Are Protected in International Law' (2010) 21 EJIL 387, 388-389.
} 
purportedly act on behalf of the community dimension of the international society ${ }^{12}$ or are required to protect persons victimized abroad.

This article will examine the tensions and paradoxes generated by the focus on territoriality and effectiveness, focusing first on those related to Statehood and territorial dominion; and will also explore how to address the needs and demands of protecting community interests in a legal landscape that, while being still closely tied to territorial subjects -States-, has the mission of properly regulating a globalized and transnational society.

\section{THE INTEGRITY OR EROSION OF BORDERS, AND Tensions CREATEd by Legal GaPS}

Statehood and territory are deeply intertwined, given how the latter is one of the defining features and a condition of existence of the former. This is stipulated in the Montevideo Convention on the Rights and Duties of the States, which under article 1 considers a 'defined territory' as one of the conditions that entities must have to be regarded as States. Furthermore, while the aforementioned Convention is an American treaty, the territorial requirement is part of customary international law.

The centrality of territory in relation to Statehood generates tensions in political and legal terms. The political tensions arise due to the fact that in the contemporary context many groups desire to achieve Statehood for a variety of purposes, ranging from nationalistic discourses to perceptions about being oppressed by majorities, among others. This creates inevitable tensions, due to the fact that there is an overlap between the desire of some groups to achieve independence, which requires dominion over a given territory, and the likely goal of the State currently having jurisdiction over such territory to retain it.

Needless to say, while proclamations and aspirations of secession may be more or less justified and legitimate, sometimes groups invoke certain political grounds for independence in cases in which they could enjoy greater self-determination remaining in a given State. In this regard, it is important to recall that self-determination may be enjoyed within a State, since independence is not the only possible manifestation of self-government. In this sense, Principle VI of UN General Assembly Resolution 1541 (XV) says that a non-self-governing territory can achieve self-government not only by emerging as a 'sovereign independent State', but also by freely associating or integrating with a State; while General Assembly Resolution 2625 (XXV) adds that self-determination may also be achieved through 'any other political status freely determined by a people'. Additionally, the extent of the right of self-determination for certain groups does not grant a right to independence, as has been indicated in doctrine. ${ }^{13}$ In this sense, for instance, the United Nations Declaration on the Rights of Indigenous Peoples mentions in article 46 that it cannot be interpreted as 'authorizing or encouraging action which would dismember or impair, totally or in part, the territorial integrity or

\footnotetext{
12 Antonio Cassese, 'Remarks on Scelle's Theory of "Role Splitting" (dédoublement fonctionnel) in International Law’ (1990) 1 EJIL 210, 215, 228-231.

${ }^{13}$ Antonio Remiro Brotóns et al., Derecho Internacional: Curso General (Tirant Lo Blanch 2010) 111-112, 124-127.
} 
political unity of sovereign and independent States'. Therefore, references to self-determination in that instrument, as in the Preamble and arts 3 and 4, are understood as having an internal expression, in the sense that they grant the right of autonomy, self-government and certain decisions for the purposes of their internal affairs, without granting a right of secession. ${ }^{14}$ Still, the lure of effectiveness may remain, and so even when refusing grounds for independence, international law promises it to those who de facto achieve it.

The different sides embroiled in political clashes and initiatives over secession versus territorial integrity tend to end up resorting to legal arguments, both of a domestic and an international nature. Concerning the former, the different sides seek to determine if and under what circumstances constitutional and local norms foresee or prevent the possibility of secession; while, curiously, international law is often invoked to support aspirations of independence even when domestic law offers no possibility of secession, but such invocations often rely on vague principles that actually fail to clearly grant a right to secession. Conversely, territorial integrity is invoked to deny aspirations of independence no matter how legitimate they are. Again, effectiveness looms large, and so independentist groups seek to convince others (and the State they are in) with emotional arguments wrapped in pseudo-legal or fully legal arguments to recognize their independence, in the hopes that eventually they will effectively operate as an independent State and so become one.

As a result, the inevitable question is whether international law says anything meaningful about secession causes. Except for cases of foreign domination in the form of colonization or occupation, or clashes against racist regimes, ${ }^{15}$ not so much. International law is largely silent, endorsing territorial integrity and thus the stability of borders while also favouring a contradictory trend pointed out above: effectiveness. In this sense, the fact that effective control over territory by those who seek secession and achieve it from a practical point of view ends up being rewarded with Statehood constitutes a lure or a temptation for groups seeking independence to try to achieve it practically, in the hopes that doing so will endow them with formal independence afterwards. Interestingly, the Canadian Supreme Court said that, concerning de facto secession, ' $[\mathrm{t}]$ he ultimate success of such a secession would be dependent on effective control of a territory'. ${ }^{16}$ While that Court also mentioned recognition as a condition of success, this element is frequently regarded as having merely a declaratory effect, without recognition being regarded as a condition of State existence. Nevertheless, even if Statehood without recognition is theoretically possible, the respective State entity will not have many opportunities of interaction and so will have its

\footnotetext{
14 ibid 133; Rafael García-Pérez, 'Recensión de: Pons Rafols, X., Cataluña: Derecho a decidir y Derecho internacional, Editorial Reus, Madrid, 2015, 334 pp.' (2015) 30 REEI 1, 2-3.

${ }^{15}$ United Nations General Assembly Resolution 1514 (XV) [1960]; Protocol Additional to the Geneva Conventions of 12 August 1949 and relating to the Protection of Victims of International Armed Conflicts (Protocol I), art 1.4; United Nations General Assembly Resolution 2625 (XXV) [1970]; Remiro Brotóns (n 13) 114-117, 120-124, 127.

${ }^{16}$ SC of Canada [1998] Reference re Secession of Quebec File No.: 25506.
} 
dynamics seriously curtailed. ${ }^{17}$ After all, while recognition by third States, in spite of being formally declaratory but not constitutive of States, has undeniable rewarding consequences by permitting international social exchanges and participation, and so facilitating effectiveness. ${ }^{18}$

In the end, while formally favouring the stability of the territorial division of the world, the role of effectiveness in international law ends up stimulating instability and, except for some serious abuses, diminishing the role of territorial integrity. This is one of the paradoxes created by the role of territory in international law, which is one of the components defining States, which in turn are regarded as the central players in the international legal landscape in important aspects such as law-making. ${ }^{19}$

Some developments may alleviate the seeming contradiction between effectiveness and legal principles, such as territorial integrity (when territory is effectively conquered by force) or human rights (when seriously abused populations are prevented from deciding their future). Firstly, an important legal development determines that effective territorial gains by third States or by groups who achieve a 'separate existence', no matter how effective in practice, produce no legal effects if such effectiveness was brought about in a way contrary to peremptory law, such as when the prohibition on the use of force was breached. ${ }^{20}$ Practice confirms this: UN General Assembly Resolution 68/262, for instance, affirming the 'sovereignty, political independence, unity and territorial integrity of Ukraine' called upon all States (hint, Russia) to 'desist and refrain from actions aimed at the partial or total disruption of the national unity and territorial integrity of Ukraine, including any attempts to modify' its borders through the threat or use of force 'or other unlawful means'.

This confirms three important legal developments and trends: a) first, that effective territorial gains by non-state groups who violate peremptory law are also denied legal relevance and validity, as evinced by the denial of Statehood to ISIS in spite of the fact that it may have met requirements set forth in the Montevideo Convention, given its serious violations and abuses. This demonstrates a willingness in international practice and opinio juris to negate the role of effectiveness in cases of serious abuses committed by both State and non-state actors, by virtue of what can be called an element of 'legitimacy', as argued by Yuval Shany, Amichai Cohen and Tal Mimran. ${ }^{21}$

17 José Manuel Cortés-Martín, Las Organizaciones Internacionales: Codificación y Desarrollo Progresivo de su Responsabilidad Internacional (Instituto Andaluz de Administración Pública 2008) 107-108; Remiro Brotóns (n 13) 81-83.

${ }^{18}$ Remiro Brotóns (n 13) 81-83; Montevideo Convention on the Rights and Duties of the States, art 3; Cortés-Martín (n 17) 103-111.

${ }^{19}$ d'Aspremont (n 6).

${ }^{20}$ Remiro Brotóns (n 13) 78-79.

${ }^{21}$ Yuval Shany, Amichai Cohen and Tal Mimran, 'ISIS: Is the Islamic State Really a State?' (The Israel Democracy Institute, $14 \quad$ September 2014) <http://en.idi.org.il/analysis/articles/isis-is-the-islamic-state-really-a-state/>; Joe Boyle, 'Islamic State and the idea of statehood' (BBC News, 6 January 2015) $<$ http://www.bbc.com/news/world-middle-east-30150681>; Adele Belanger-McMurdo, 'A Fight for Statehood? ISIS and Its Quest for Political Domination' (E-International Relations Students, 5 October 2015) <http://www.e-ir.info/2015/10/05/a-fight-for-statehood-isis-andits-quest-for-political-domination/> accessed 27 June 2018; Montevideo Convention on the Rights and Duties of the States, art 11. 


\section{STATEHOOD AND INTERNATIONAL NORMS AS AN \\ OBSTACLE TO THE PROTECTION OF INTERNATIONAL COMMUNITY INTERESTS}

b) Secondly, that seizure by States of the territory of other States absent the free consent of the latter lack validity, and such consent is invalid if obtained through coercion or outright conquest. ${ }^{22}$ And c) that in addition to the condemnation of direct land or territorial grabs, since 'any action aimed at the partial or total disruption of the national unity and territorial integrity of any' State" is forbidden; as Resolution 2625 (XXV) puts it, it can be inferred that indirect disruption of such integrity or supporting third parties (State or not) which affect it are also prohibited, as confirmed by the International Law Commission. ${ }^{23}$

An interesting idea ensues: not only are States obliged to refrain from disrupting or contributing to the violation of the territorial integrity of other States, but they are also under an obligation to not negatively affect, recognize or assist the violation of the right of self-determination of peoples more generally, not only when States are its beneficiaries. ${ }^{24}$ In this regard, it is interesting to note that the arguments of the International Court of Justice in its advisory opinion on the Legal Consequences of the Construction of a Wall in the Occupied Palestinian Territory indicate and confirm that the principle of self-determination of peoples not only benefits States and grants peoples a right that has an erga omnes nature, thus imposing obligations on every member of the international society to respect such right, to assist in promoting its respect and to not contribute to its violation. ${ }^{25}$

An additional development that may eliminate an undue role of effectiveness is the consideration that in cases of extreme human rights violations there is a 'remedial' right to separation of seriously and systematically subjugated or persecuted peoples (being those peoples identified by factual, and not legal, features), which thus entitles them to independence even if they have not successfully attained through an armed struggle or by other means. ${ }^{26}$ The positive law status of this latter trend, however, is still unclear in many aspects and developing.

Moreover, in cases which are not so extreme the possibility of secession by virtue of effectiveness is not precluded, provided that jus cogens is respected. In such cases, the paradox persists and may sadly encourage clashes between opposing actors which invoke legitimacy arguments but end up seeking effective control. After all, there is a stimulus when the prospect of the reward of either territorial integrity or secession can be achieved through securing effectiveness. In relation to this, it is important to keep in

\footnotetext{
${ }^{22}$ Vienna Convention on the Law of Treaties, arts 48-52; International Law Commission, 'Draft articles on Responsibility of States for Internationally Wrongful Acts, with commentaries, 2001' (2001) Yearbook of the International Law Commission [4 of the commentary to art 20], art 20, 72-73.

23 International Law Commission, 'Draft articles on Responsibility of States for Internationally Wrongful Acts, with commentaries, 2001' (2001) Yearbook of the International Law Commission [6-7 of the commentary to art 41], 114-115.

24 ibid [8 of the commentary to art 41] 115.

${ }^{25}$ Legal Consequences of the Construction of a Wall in the Occupied Palestinian Territory, Advisory Opinion, I.C.J. Reports 2004, 136 [88], [115], [118], [122], [149], [155], [159].

${ }^{26}$ Remiro Brotóns (n 13) 127-129; Separate Opinion of Judge Cançado Trindade to: Accordance with International Law of the Unilateral Declaration of Independence in Respect of Kosovo, Advisory Opinion, I.C.J. Reports 2010 [174]-[186], [228].
} 
mind that the prospect of obtaining legally-sponsored benefits or 'rewards' territorial-related, in our case- is an encouragement that can play a central role as a factor explaining the conduct of actors participating in the international society. ${ }^{27}$

Regarding the aforementioned 'remedial' secession in extreme cases, one can consider that the starting point is that law favours territorial integrity and stability. After all, that is a Principle of international law enshrined in arts 2.4 of the United Nations Charter and 1 of the Charter of the Organization of American States, among others, apart from being present in customary law and invoked in international fora. ${ }^{28}$ Practically speaking, it is hard (impossible?) to think of States that do not commit human rights violations, as evinced by their reluctance to resort to inter-State complaints, perhaps out of fear of being complained about their own abuses in turn. ${ }^{29}$ This explains why the remedial secession based on serious human rights violations tends to be construed as being exceptional and not arising out of any human rights violation, ${ }^{30}$ lest instability is promoted by law. Practice, which after all has a role in the interpretation of international law, as indicated in art 31 of the Vienna Convention on the Law of Treaties, confirms this. This is how one can construe General Assembly Resolution 2625 (XXV), when it says that:

'Nothing in the foregoing paragraphs shall be construed as authorizing or encouraging any action which would dismember or impair, totally or in part, the territorial integrity or political unity of sovereign and independent States conducting themselves in compliance with the principle of equal rights and self-determination of peoples as described above and thus possessed of a government representing the whole people belonging to the territory without distinction as to race, creed or colour.'

Apart from its exceptionality, the content and contours of the so-called remedial secession ${ }^{31}$ are still developing and some may or may never crystallize into norms envisaging broader or clearer circumstances granting a right to secession. After all, other international developments, such as the potentially 'emerging' ${ }^{32}$ right to 'humanitarian intervention', ended up saying the same that the United Nations Charter already says, without adding any additional right to use force apart from self-defence or authorization by the Security Council. ${ }^{33}$ That being said, insofar as conduct that contradicts

\footnotetext{
${ }^{27}$ Harold Hongju Koh, 'Why Do Nations Obey International Law?' (1997) 106 The Yale Law Journal 2599, 2600-2601.

${ }^{28}$ Accordance with International Law of the Unilateral Declaration of Independence in Respect of Kosovo, Advisory Opinion, I.C.J. Reports 2010, p. 403 [80]; Tatiana Waisberg, 'Colombia's Use of Force in Ecuador Against a Terrorist Organization: International Law and the Use of Force Against Non-State Actors' (2008) 12 ASIL Insights.

${ }^{29}$ Eric A Posner, The Twilight of Human Rights Law (OUP 2014) 79-80.

${ }^{30}$ Remiro Brotóns (n 13) 127-129.

${ }^{31}$ Separate Opinion of Judge Cançado Trindade to: Accordance with International Law of the Unilateral Declaration of Independence in Respect of Kosovo, Advisory Opinion, I.C.J. Reports 2010 [175]; Steven R. Ratner, The Thin Justice of International Law: A Moral Reckoning of the Law of Nations (OUP 2015) 149, 165, 169.

32 Antonio Cassese, 'Ex iniuria ius oritur: Are We Moving towards International Legitimation of Forcible Humanitarian Countermeasures in the World Community?' (1999) 10 EJIL 23, 29.

${ }^{33}$ United Nations, A more secure world: Our shared responsibility, Report of the High-level Panel on Threats, Challenges and Change [2004] 13, 65-66, 106.
} 


\section{STATEHOOD AND INTERNATIONAL NORMS AS AN \\ OBSTACLE TO THE PROTECTION OF INTERNATIONAL COMMUNITY INTERESTS}

existing international norms may end up leading to future different norms, ${ }^{34}$ it may happen that additional cases in which an exception to territorial integrity is envisaged arise in the future if sufficient practice and legal opinion support them.

Apart from the cases of (State and non-state) territorial gains obtained by violating peremptory law and extreme cases of remedial secession, the role and legal effects attached to effectiveness make international law fail to settle disputes. Why? Because lip service to territorial integrity does not prevent the emergence of tensions and problematic cases of abuses which are not so extreme are not given a solution. Thus, tensions cannot be solved by resorting to international law exclusively, since ultimately neither territorial integrity nor human rights or self-determination arguments fully operate as 'trumps' or decisive winning cards, except in exceptional circumstances, given how the potential of 'effective' victory by the other party looms as a threat. Thus, insofar as politics and power are the decisive factors, one could be tempted to think that international legal discourses would be abandoned by the conflicting sides in secession disputes, but this is not what happens.

Actually, both those who seek to attain independence or to ensure the persistence of existing State borders invoke international legal arguments, but curiously often they advance their own self-serving interpretations and legal aspirations even if they fail to actually reflect international regulation. This is a manifestation of what Jan Klabbers has identified as dynamics by means of which different actors invoke and interpret international law, providing discourses either to subvert or maintain the status quo and bolster their own position. ${ }^{35}$ This is stimulated by the legal ambiguity. For instance, those who are interested in dismembering territories may desire to benefit from the vagueness of international law and seek to obtain legitimacy by invoking broad principles, even if they do not directly confer what they seek.

This explains why some come up with discourses based on either selfdetermination, as some Catalonian independentists, or on territorial integrity, as the Spanish and Chinese governments do. Interestingly, some of the actors invoking these arguments lack international legal personality and are local actors that seek to express their voice in the world society, but this is no reason to dismiss their international legal relevance. Rosalyn Higgins well pointed out that rather than insisting on subjectivity it is important to look at how different formal and informal actors operate as participants interacting with international law, making claims so as to 'maximiz[e] various values' ${ }^{36}$ And as Myres McDougal considered, such interaction is not only institutional and formal, insofar as both official and other actors may come up with different strategies, discourses and interpretations invoking international law to promote their policy objectives. ${ }^{37}$ In the case under examination, discourses are often invoked by parties with asymmetrical power, a reason why the weak

\footnotetext{
${ }^{34}$ Cassese, 'Ex iniuria ius oritur' (n 32) 29-30; Remiro Brotóns (n 13) 213.

${ }^{35}$ Klabbers (n 7) 308-309.

${ }^{36}$ Rosalyn Higgins, Problems \& Process: International Law and How We Use it (OUP 2004) 50 .

${ }^{37}$ Myres S. McDougal and Harold D. Lasswell, 'The Identification and Appraisal of Diverse Systems of Public Order' (1959) 53 AJIL 1, 8-10.
} 
may desire to rely on the only tool at its disposal: the (correct or inaccurate) invocation of law. Interestingly, non-intervention and sovereign arguments have for long been used to protect the weaker party. For instance Emmer de Vattel invoked them when seeking the protection of Republican or weak States from stronger or imperial ones, defending non-intervention and integrity save for some extreme cases, although his theories undermined nonstate and individual relevance. ${ }^{38}$ In this sense, Vattel said that 'Since men are naturally equal, and a perfect equality prevails in their rights and obligations, as equally proceeding from nature,- nations composed of men, and considered as so many free persons living together in the state of nature, are naturally equal, and inherit from nature the same obligations and rights. Power or weakness does not in this respect produce any difference. A dwarf is as much a man as a giant; a small republic is no less a sovereign state than the most powerful kingdom'. ${ }^{39}$

Thus, in spite of the paradoxes generated by effectiveness and the ambiguity of territorial integrity, which lead to certain factual gaps, sub-state participants in the world society will seek to benefit from discourses that lend support to their arguments, especially trying to convince others about their 'legal soundness' in ways that confuse their policies with lex lata. This explains why some grassroots and other independence movements convey messages relying on notions as self-determination even if they do not truly directly grant the rights they invoke. Why do they do that? These actors may desire to benefit from the so-called expressive effects of international law. If they manage to convince others that law favours them, they may shape the attitudes of others by means of convincing them to espouse legal changes or interpretations ${ }^{40}$ and to recognize their legitimacy. This is not irrelevant, since the support of powerful States may pave the way for effectiveness when these powers challenge the States from which the actors attempt to secede. Symbolic strategies should not be underestimated because, after all, legal arguments can have a cultural impact, which explains both the so-called cultural wars' reliance on judiciaries and dynamics of lawfare, which to my mind may be understood in a broad sense and not only related to strategies replacing the use of force in relation to security issues. ${ }^{41}$ Interestingly, in this case expressive effects are generated without a clear legal basis, but rather their success depends on portraying the appearance of such a basis, given the ambiguous stance of international law.

\footnotetext{
${ }^{38}$ Jennifer Pitts, 'Intervention and sovereign equality: legacies of Vattel' in Stefano Recchia and Jennifer M. Welsh (eds), Just and Unjust Military Intervention: European Thinkers from Vitoria to Mill (CUP 2013) 140-150; Thomas H. Lee, 'International Law, International Relations Theory, and Preemptive War: The Vitality of Sovereign Equality Today' (2004) 67 Law and Contemporary Problems 147, 150-153.

${ }^{39}$ Emer de Vattel, The Law of Nations, Or, Principles of the Law of Nature, Applied to the Conduct and Affairs of Nations and Sovereigns, with Three Early Essays on the Origin and Nature of Natural Law and on Luxury (LF ed 1797) <http://oll.libertyfund.org/titles/vattelthe-law-of-nations-lf-ed> accessed 27 June 2018, emphasis added.

${ }^{40}$ Richard H McAdams, The Expressive Powers of Law: Theories and Limits (Harvard UP 2015) 1-10; Alex Geisinger and Michael Ashley Stein, 'A Theory of Expressive International Law' (2007) 60 Vanderbilt Law Review.

${ }^{41}$ Orde F Kittrie, Lawfare: Law as a Weapon of War (OUP 2016) 1-5; Orde F. Kittrie, 'The emergence of lawfare [infographic]' (OUPblog, 16 May 2016) < https://blog.oup.com/2016/05/emergence-of-lawfare-infographic/ > accessed 27 June 2018.
} 


\section{STATEHOOD AND INTERNATIONAL NORMS AS AN \\ OBSTACLE TO THE PROTECTION OF INTERNATIONAL COMMUNITY INTERESTS}

Indeed, law is ambivalent or ambiguous, tenuously favouring territorial integrity while opening the door to effectiveness, perhaps out of fear that lack of recognition of such effective situations could lead to revolt against the international legal order by those who acquire power, and to exceptional remedial situations. This may stimulate arguments of remedial secession that either exaggerate claims on violations or lead abusive States to falsely diminish the extent of widespread or systematic violations. As to the lack of legal clarity, it is useful to recall how in its advisory opinion on the Accordance with International Law of the Unilateral Declaration of Independence in respect of Kosovo, the International Court of Justice considered that there is no general prohibition of making declarations of independence, while implicitly admitting that specific prohibitions, for instance created by bodies as the Security Council, can be created but did not exist in the case it examined, and that no such prohibition flows from the principle of territorial integrity, without examining the consequences of such declarations or their recognition by third parties. ${ }^{42}$

Additionally, the Court said that the absence of such a prohibition does not imply that there is a right to independence or to issue declarations of independence. In its words, 'it is entirely possible for a particular act — such as a unilateral declaration of independence - not to be in violation of international law without necessarily constituting the exercise of a right conferred by it' ${ }^{43}$ As judge Bruno Simma suggests, the issue is not merely a binary 'legal or illegal' question, but rather it could be said that declarations of independence may be tolerated and perhaps will or will not be further addressed in future regulation. ${ }^{44}$ This analysis of the Court confirms that international law leaves the door open for the game of effectiveness, since absent effectiveness declarations of independence are likely doomed to be largely or merely anecdotal, as happened with a declaration of selfdetermination that seemed to entail beliefs about independence of the San Andrés archipelago from Colombia; ${ }^{45}$ and if a group secures effective control it may achieve Statehood. Needless to say, political considerations about the legitimacy of those declarations of independence are different from their legal effects, but legitimacy considerations are not decisive from a legal or a political point of view, since effectiveness again reigns supreme, save for exceptional cases. Thus, the legal panorama encourages bold action by all parties involved, which is risky, or caution if success seems unlikely.

\footnotetext{
${ }^{42}$ Accordance with International Law of the Unilateral Declaration of Independence in Respect of Kosovo, Advisory Opinion, I.C.J. Reports 2010, 03 [51], [79]-[80], [112]-[119], [122].

${ }^{43}$ ibid [56].

${ }^{44}$ Declaration of Judge Simma to: Accordance with International Law of the Unilateral Declaration of Independence in Respect of Kosovo, Advisory Opinion, I.C.J. Reports 2010 [9].

45 'Declaración de Autodeterminación, San Andrés, Islas' (28 April 2002) $<$ http://www.urosario.edu.co/jurisprudencia/catedra-vivaintercultural/Documentos/DeclaracionAutodeterminacionRaizal.pdf $>$ accessed 27 June 2018.
} 
In light of the ambiguity and paradoxes resulting from the tension between territorial integrity and effective secession, which have few exceptions when there is a violation of peremptory law (preventing territorial changes) or serious breaches that are systematic (granting an exceptional entitlement to independence), ${ }^{46}$ it remains to be seen whether this scenario is legitimate and convenient, or if there is a preferable alternative de lege ferenda; and whether a territorial-centric framework can properly and fairly respond to the needs of a global contemporary society.

\section{THE IDENTITY AND FUNCTIONS OF STATES AND LEGITIMACY QUESTIONS IN A GLOBAL SOCIETY}

Two sets of considerations should guide the resolution of tensions and uncertainties about the existence, role and functions of States: those related to the humanization of international law and those addressing the challenges posed by non-state actors. As will be argued here, those considerations can contribute to dispelling doubts about remedial secession, self-defence against non-state actors and extraterritorial obligations of States.

In relatively recent times, international law has undergone a (much needed) transformation, dealing ever more with cooperation (e.g. environmental) issues instead of focusing only on coexistence aspects. ${ }^{47} \mathrm{In}$ that transformation, a process of humanization, ${ }^{48}$ which is still unfinished, is central. Thanks to the activism and initiative of actors both within and outside the system, considerations of humanity, such as those related to the protection of human dignity, have been incorporated to lesser (e.g. in investment law, a pending issue therein) or greater extent in some norms, prominently but not exclusively in human rights law and related regimes, such as the law of refugees, international criminal law or international humanitarian law. ${ }^{49}$ Moreover, thanks to interesting dynamics, norms belonging to regimes traditionally dealing with inter-State relations and coexistence issues have incorporated some indirect or direct protection of human dignity, as happens

\footnotetext{
${ }^{46}$ (n 26) and (n 31).

${ }^{47}$ Regarding the existence and tension of both the cooperation and co-existence dimensions of international law, see: Pierre-Marie Dupuy, 'International Law: Torn between Coexistence, Cooperation and Globalization. General Conclusions' (1998) 9 EJIL.

48 Theodor Meron, The Humanization of International Law (Martinus Nijhoff 2006); Concurring Opinion of Judge AA Cançado Trindade to: I/A Court H.R., Juridical Condition and Rights of the Undocumented Migrants. Advisory Opinion OC-18/03 of September 17, 2003. Series A No.18 [21]-[30]; Concurring Opinion of Judge AA Cançado Trindade to: I/A Court H.R., Juridical Condition and Human Rights of the Child. Advisory Opinion OC-17/02 of August 28, 2002. Series A No.17 [10]-[34], [45]-[50].

${ }^{49}$ Antônio Augusto Cançado Trindade, 'Derecho Internacional de los Derechos Humanos, Derecho Internacional de los Refugiados y Derecho Internacional Humanitario: Aproximaciones y Convergencias' (1996) I Estudios Especializados de Derechos Humanos; Claire de Than and Edwin Shorts, International Criminal Law and Human Rights (Sweet \& Maxwell 2003) 12-13, 29; Conference for Security and Cooperation in Europe, 1992 Summit, Helsinki, "The Challenges of Change", Helsinki Document 1992 [1992].
} 


\section{STATEHOOD AND INTERNATIONAL NORMS AS AN \\ OBSTACLE TO THE PROTECTION OF INTERNATIONAL COMMUNITY INTERESTS}

with consular assistance ${ }^{50}$ in the law of consular relations or the protection of those at peril in the law of the sea. ${ }^{51}$

Aspects related to Statehood should not be an exception to this process of humanization, especially in light of the consideration that, as expressed by Antonio Cançado, the legitimacy and raison d'être of both international law and the existence of States must be the protection and respect of individuals. ${ }^{52}$ In this sense, questions of territorial integrity cannot be an exception to the consideration that human rights must serve as standards or measures of the legitimacy and justice of its regulation.

To ensure a humanized approach to the implementation of norms on Statehood and territory, practitioners and interpreters must do two things: firstly, as far as possible, norms and institutions related to the existence of States, including those on the maintenance of existing borders -territorial integrity- and on secession, and those related to the powers of States inside their borders and abroad, must be interpreted in the way that favours the protection of human beings the most, and the most favourable norm and interpretation, in a way that can be effectively implemented, must always be chosen. This is what the pro personaelpro homine principle requires in conjunction with the effet utile. ${ }^{53}$ But apart from this, if a gap or insufficient protection that are the result of norms on Statehood are identified, this must be addressed de lege ferenda.

Apart from humanization, international legal practice and regulation have also gradually come to terms with the fact that non-state actors are central players in international and transnational relations, ${ }^{54}$ and that a proper provision of global public goods, such as those related to human rights, ${ }^{55}$ and

\footnotetext{
${ }^{50}$ I/A Court H.R., The Right to Information on Consular Assistance in the Framework of the Guarantees of the due Process of Law. Advisory Opinion OC-16/99 of October 1, 1999. Series A No.16 [72], [76], [80], [82]-[87], [115], [121]-[124]; I/A Court H.R., "Other treaties" subject to the consultative jurisdiction of the Court (Art. 64 American Convention on Human Rights). Advisory Opinion OC-1/82 of September 24, 1982. Series A No. 1 [34]. ${ }^{51}$ As follows when applying the considerations expressed in the preceding footnote to articles 24, 96, 98 through 101, and 146 of the United Nations Convention on the Law of the Sea; IMO, UNHCR and International Chamber of Shipping, Rescue at Sea: A guide to principles and practice as applied to migrants and refugees <http://www.unhcr.org/450037d34.pdf> accessed 27 June 2018.

${ }^{52}$ Separate Opinion of Judge Cançado Trindade to: Accordance with International Law of the Unilateral Declaration of Independence in Respect of Kosovo, Advisory Opinion, I.C.J. Reports 2010, 403 [239]; Concurring Opinion of Judge AA Cançado Trindade to: I/A Court H.R., Juridical Condition and Human Rights of the Child. Advisory Opinion OC-17/02 of August 28, 2002. Series A No.17 [13], [19].

${ }^{53}$ Mónica Pinto, 'El principio pro homine. Criterios de hermenéutica y pautas para la regulación de los derechos humanos' in Martín Abregú and Christian Courtis (eds), La aplicación de los tratados sobre derechos humanos por los tribunales locales (Centro de Estudios Legales y Sociales 1997); Malgosia Fitzmaurice, 'Interpretation of Human Rights Treaties' in Dinah Shelton (ed), The Oxford Handbook of International Human Rights Law (OUP 2013) 755-756; José Pedro Aguirre Arango, 'La interpretación de la Convención Americana sobre Derechos Humanos' 80-81 <http://www.corteidh.or.cr/tablas/R22853.pdf $>$ accessed 26 May 2016.

54 del Arenal (n 3) 34, 62-66, 70-71, 77.

55 Inge Kaul, Pedro Conceiçao, Katell Le Goulven and Ronald Mendoza, 'How to Improve the Provision of Global Public Goods' in Inge Kaul et al. (eds) Providing Global Public
} 
an adequate and full protection of international legal interests, cannot be effective without considering the contributions and challenges of those actors, which demands, among others, subjecting them to rule of law considerations ${ }^{56}$ and ensuring the protection of victims of their abuses.

Properly dealing with non-state threats when examining Statehood issues is necessary for the norms regulating them to be relevant and not outdated. This requires considering, in the first place, that nowadays there are many transnational threats and lack of coordination between States that may pave the way for impunity by actors that 'jump' jurisdictions, evading State controls $;{ }^{57}$ and secondly that there are serious non-state threats originating in State territories without there being a direct attribution of non-state conduct to the territorial State. In these cases, the respective actor may victimize peoples found in other States, and it may be unfair to condemn those peoples to victimization and lack of protection on the basis of a traditional territorial conception according to which only the territorial State is entitled to do something. ${ }^{58}$

This problem exists when non-state armed groups carry out attacks that amount to major uses of force while hiding in foreign territories, a reason why a trend to permit self-defence against them has arisen. Obviously, it would be inadequate to permit an unfettered intervention by all States, and thus controls and conditions must be set in place. Accordingly, those who favour the possibility of exercising self-defence against non-state actors say that, in addition to the general conditions for the exercise of self-defence an additional requirement must be satisfied: a test according to which it is demonstrated that the territorial State is either unwilling or unable to deal with the non-state threat itself. ${ }^{59}$ That being said, this possibility of self-defence against non-state threats is contested by some, either for political reasons, according to which permitting this could lead to escalations or expansive uses of force, ${ }^{60}$ or by those who argue that there is insufficient practice and opinio

Goods (OUP 2003) 37, 44; Inge Kaul and Ronald Mendonza, 'Advancing the Concept of Public Goods' in Inge Kaul et al. (eds) Providing Global Public Goods (OUP 2003) 95 82-83, 84, 86, 97-98, 100, 106.

${ }^{56}$ Janne E Nijman, 'Non-state actors and the international rule of law: Revisiting the 'realist theory' of international legal personality"' (2010) Amsterdam Center for International Law Research Paper Series 1, 7-19, 40.

${ }^{57}$ Human Rights Council, Report on the first session of the open-ended intergovernmental working group on transnational corporations and other business enterprises with respect to human rights, with the mandate of elaborating an international legally binding instrument, Chair-Rapporteur: María Fernanda Espinosa, A/HRC/31/50 [2016] [50].

${ }^{58}$ Separate Opinion of Judge Kooijmans to: International Court of Justice, Armed Activities on the Territory of the Congo (Democratic Republic of the Congo v Uganda), Judgment, I.C.J. Reports 2005 [30].

${ }^{59}$ See: Arabella Lang, 'Legal basis for UK military action in Syria' (2015) 7404 United Kingdom House of Commons Library Briefing Papers 1, 3-4, 14-15, 17-17; Waisberg (n 28); Marko Milanovic, 'Self-Defense and Non-State Actors: Indeterminacy and the Jus ad Bellum' (EJIL: Talk!, 21 February 2010) <http://www.ejiltalk.org/self-defense-and-nonstate-actors-indeterminacy-and-the-jus-ad-bellum/>; Jens David Ohlin, 'The Unwilling or Unable Doctrine Comes to Life' (Opinio Juris, 23 September 2014) <http://opiniojuris.org/2014/09/23/unwilling-unable-doctrine-comes-life/> accessed 27 June 2018.

${ }^{60}$ Constantine Antonopoulos, 'Force by Armed Groups as Armed Attack and the Broadening of Self-Defence' (2008) LV Netherlands International Law Review. 


\section{STATEHOOD AND INTERNATIONAL NORMS AS AN \\ OBSTACLE TO THE PROTECTION OF INTERNATIONAL COMMUNITY INTERESTS}

juris about this possibility, ${ }^{61}$ a reason why such exercises would infringe territorial integrity, as some OAS States -with the exception of the United States- argued when Colombia attacked the FARC guerrillas in Ecuadorian territory. ${ }^{62}$ That being said, the Security Council, some judges of the International Court of Justice and the practice and opinion of some States, such as Israel, the United Kingdom, the United States of America, Colombia or Turkey favour the possibility of conducting self-defence against non-state actors located in foreign territories. This debate demonstrates once again how territory may be a hindrance or an obstacle to other principles of international law such as the protection of victims. This is one of the causes of tension between principles of this legal system, ${ }^{63}$ and dealing with them requires bearing in mind all of the relevant principles without utterly denying any, considering their hierarchy and a proportionality analysis.

Territory is also present in questions on what States should do in terms of protecting human rights. In this regard, the rationale expressed in the Corfu Channel case, according to which States have the duty 'not to allow knowingly its territory to be used for acts contrary to the rights of other States', may be pertinent, even if its original mention was about the protection of the rights of other States by a State in its own territory. In the famous Island of Palmas Arbitral Award this idea was expressed in the following words: there is an obligation of States 'to protect within [their] territory the rights of other States, in particular their right to integrity and inviolability in peace and in war' ${ }^{64}$ However, this is complemented by the human rights consideration that States must protect all individuals in their territories. Yet, while important, this demand is not sufficient in light of the needs of effective protection in a complex world in which States commit abuses abroad and transnational actors evade State controls.

This explains why States must also respect the rights of those under their jurisdiction when that jurisdiction takes place outside their territory, as has been expressed by the Inter-American Commission on Human Rights, United Nations Human Rights Committees, or the European Court of Human Rights. ${ }^{65}$ This is a necessary development that is still being discussed,

${ }^{61}$ Kevin Jon Heller, 'France Fails to Adopt "Unwilling or Unable” in Syria' (Opinio Juris, 11 October 2015) <http://opiniojuris.org/2015/10/11/france-fails-to-adopt-unwilling-orunable-in-syria/>; Kevin Jon Heller, 'The Seemingly Inexorable March of "Unwilling or Unable" Through the Academy' (Opinio Juris, 6 March 2015) <http://opiniojuris.org/2015/03/06/the-seemingly-inexorable-march-of-unwilling-orunable-through-the-academy/> accessed 26 May 2016. On state support and rejection of the doctrine of 'unwilling or unable', see Elena Chachko and Ashley Deeks, 'Who is on Board with "Unwilling or Unable"? (Lawfare, 10 October 2016) < https://www.lawfareblog.com/who-board-unwilling-or-unable\#Venezuela > accessed 27 June 2018.

${ }^{62}$ Waisberg (n 28)

${ }^{63}$ McDougal and Lasswell (n 37) 3-5.

${ }^{64}$ International Court of Justice, Corfu Channel case, Judgment of April 9th, 1949: I.C.J . Reports 1949 1, 18, 22; Reports of International Arbitral Awards, Vol II, Island of Palmas case (Netherlands, USA) 4 April 19, 839.

${ }^{65}$ Inter-American Commission on Human Rights, Towards the Closure of Guantanamo, OAS/Ser.L/V/II, Doc. 20/15 [2015], [54]; International Court of Justice, Legal Consequences 
especially in the human rights system of the Council of Europe, insofar as therein the issue is still debated and it is still to be seen whether jurisdiction is considered to also exist based on the human rights effects or impact of State authorities abroad or only whether a certain control (general territorial control or specific control over persons or territories) is present. ${ }^{66}$ Nonetheless, if extraterritorial State jurisdiction is found to exist, it is not questioned that States are required to respect human rights extraterritorially, that is to say to refrain from affecting them. ${ }^{67}$ Furthermore, as legal developments indicate, apart from possible emerging extraterritorial duties, sometimes States are permitted or encouraged to exercise extraterritorial jurisdiction to protect from non-state abuses taking place abroad even if they are not under an obligation to do so. ${ }^{68}$

A different and more complicated question is whether States should also be under positive obligations to ensure or protect human rights extraterritorially, i.e. beyond their own borders. This has been discussed, for instance, in the context of business and human rights debates. According to the Guiding Principles on Business and Human Rights and the InterAmerican Commission on Human Rights, while States are permitted to respond to non-state human rights abuses attributable to actors as corporations that take place beyond their borders, they are not under an obligation to do so

of the Construction of a Wal in the Occupied Palestinian Territory, Advisory Opinion, I.C.J. Reports 2004, 136 [108]-[113]; Marko Milanovic, 'Jurisdiction, Attribution and Responsibility in Jaloud' (EJIL: Talk!, 11 December 2014) $<$ http://www.ejiltalk.org/jurisdiction-attribution-and-responsibility-in-jaloud/\#more12706>; Marko Milanovic, 'A Few Thoughts on Hassan v United Kingdom' (EJIL: Talk!, 22 October 2014) <http://www.ejiltalk.org/a-few-thoughts-on-hassan-v-united-kingdom/>; Stuart Wallace, 'Refining Al-Skeini v UK: The ECtHR's Grand Chamber hearing in Jaloud v Netherlands' (EJIL: Talk!, 7 March 2014) <http://www.ejiltalk.org/refining-al-skeini-v-ukthe-ecthrs-grand-chamber-hearing-in-jaloud-v-netherlands/>; Marko Milanovic, 'Al-Skeini and Al-Jedda in Strasbourg' (EJIL: Talk!, 29 August 2011) <http://www.ejiltalk.org/alskeini-and-al-jedda-in-strasbourg/>; Marko Milanovic, 'Extraterritorial Application of Human Rights Treaties: An Overview' (EJIL: Talk!, 30 November 2011) <http://www.ejiltalk.org/extraterritorial-application-of-human-rights-treaties-an-overview/> accessed 27 May 2016.

${ }^{66}$ ibid.

${ }^{67}$ I/A Court H.R., Case of Velásquez Rodríguez v Honduras. Merits. Judgment of July 29, 1988. Series C No. 4 [155]-[156], [161], [164]-[166], [169]; Maastricht Principles on Extraterritorial Obligations of States in the Area of Economic, Social and Cultural Rights, Principle 20.

${ }^{68}$ United Nations, Guiding Principles on Business and Human Rights: Implementing the United Nations "Protect, Respect and Remedy Framework" [2011] 1, 3-4, commentary to Principle 2; Committee on Economic, Social and Cultural Rights, General comment No. 23 (2016) on the right to just and favourable conditions of work (article 7 of the International Covenant on Economic, Social and Cultural Rights), E/C.12/GC/23, 27 April 2016 [60]-[70]; Committee on the Elimination of Discrimination against Women, General recommendation No. 34 (2016) on the rights of rural women, CEDAW/C/GC/34 [2016], [13]; Committee on Economic, Social and Cultural Rights, General comment No. 22 (2016) on the right to sexual and reproductive health (article 12 of the International Covenant on Economic, Social and Cultural Rights), E/C.12/GC/22 [2016], [60]; Inter-American Commission on Human Rights, Indigenous Peoples, Afro-Descendent Communities, and Natural Resources: Human Rights Protection in the Context of Extraction, Exploitation, and Development Activities (also known as 'Indigenous Peoples, Communities of African Descent, Extractive Industries), OEA/Ser.L/V/II, Doc. 47/15 [2015], [77]-[81]. 
unless a violation is attributable to those States. ${ }^{69}$ This traditionalistic criterion has begun to be challenged by some human rights bodies that encourage States to conduct such extraterritorial protection, arguing that they should offer it. ${ }^{70}$ Furthermore, a group of experts adopted the Maastricht Principles on Extraterritorial Obligations of States in the Area of Economic, Social and Cultural Rights, in which they argue that States must have extraterritorial obligations when they have a connection of nationality, substantial business or domicile with a corporation, when the abuse originates in their territory or when they have other close links to businesses operating abroad, among others, as reflected in Principle 25. ${ }^{71}$

These efforts are necessary, and I defend the idea that progressive development should end up by adopting hard law extraterritorial obligations of protection. The reason why is that in our interdependent world States may benefit from corporate conduct taking place abroad or may be the only ones with sufficient leverage or power to protect from their abuses, given the insufficient means of some developing States to protect victims of corporate abuse despite their best efforts and diligence. A similar criterion may inspire universal jurisdiction. It must be added that corporations in multinational groups can dissolve or relocate, and so easily evade jurisdiction. This evinces the limits of an international law centred on State territories, because lack of coordination, different regulations and capacities of implementation and transnational actors may hinder the protection of victims and the accountability of offenders, making an excessively territorially-focused system outdated in light of the need to tackle global challenges.

That international law can evolve and provide adequate protection by overcoming the limits of State and territorial features are demonstrated in the human rights practice providing protection against abuses in a territory even if a State is not responsible. This happens, for example, when territories are controlled or administered by non-state entities while nominally remaining under a given State's jurisdiction. When a territory is provisionally administered by an international body, as happened with UNMIK in Kosovo, or when non-state groups de facto control territories and engage in abuses, as some groups have done in Somalia, international human rights bodies such as the Human Rights Committee and the Committee against Torture, have relied on the notion that, more than focusing on States, it is important to focus on individuals and the rights they are entitled to, regardless of who controls the respective territory, reason why they could claim international protection from abuses that the non-state entities can engage in. Likewise, authors as José Manuel Cortés argue that international bodies and organizations that administer territories should have responsibility for what they do when exercising such a function. ${ }^{72}$

\footnotetext{
69 ibid.

${ }^{70}$ See the references in the two preceding footnotes.

${ }^{71}$ Maastricht Principles on Extraterritorial Obligations of States in the Area of Economic, Social and Cultural Rights, Principles 24-26, 36-37.

72 Human Rights Committee, Concluding Observations on Kosovo (Serbia), CCPR/C/UNK/CO/1 [2006], [4], [8]-[22]; Cortés-Martín (n 17) 204-211.
} 
All of the previous considerations indicate that paradoxes and tensions must be resolved by looking at human rights. Yet, just as human dignity needs human rights to provide functional protection in many cases, human rights law in turn does not always offer clear or absolute answers. ${ }^{73}$ Hence, it may be important to consider the protection of human dignity alongside the guarantee of other principles, such as security and peace, the breach of which seriously affects individuals, as argued by Steven R. Ratner. ${ }^{74}$ With them in mind, what can be said about 'remedial' secession? That in extreme cases in which rights are utterly denied to a given people and it is demonstrated on a case-by-case basis that it is necessary, there being no alternative that affects territorial integrity less, peoples have a right to secede, even if they have no factual possibility to achieve it. ${ }^{75}$ To my mind, in these cases even absent effectiveness they can acquire independence and others must recognize it when not doing so implies accepting a status quo of serious (e.g. gross or systematic $)^{76}$ violations of those human rights norms that are peremptory and inaction. ${ }^{77}$ In all other cases, peoples have rights of internal selfdetermination and protection form State abuses, which may amount sometimes to permitting displacing territorial administration in favour of international authorities or requiring international supervision and monitoring, for instance by peacekeeping operations. Altogether, territorial integrity is important but is not an absolute value, and cannot trump human rights. Yet, if a proportional balance can be struck in cases of abuses that are not so extreme. Alternatives are preferable to granting independence to every single movement, since this can stir or breed instability and conflicts, provided that internal self-determination is respected.

This is because favouring an endless possibility of disintegration against the will of the territorial State promotes instability and possible conflicts, for instance due to the fact that within new States there may be abuses against others, as some say may have happened against Kosovo Serbs or in Northern Kosovo. ${ }^{78}$ Yet, even in the absence of an international right to secession, it is convenient for domestic law to provide venues of democratic discussion about these issues to prevent violent or extreme movements. Perhaps an entitlement to such discussions should be adopted under international law. Accordingly, for practical and political reasons, States

\footnotetext{
${ }^{73}$ Roberto Andorno, 'Human Dignity and Human Rights as a Common Ground for a Global Bioethics' (2009) 34 Journal of Medicine and Philosophy; Posner (n 29) 17, 33, 36, 41, 47, 65, 86-87, 96, 103-104, 121.

${ }^{74}$ Ratner (n 31) 65-69, 73, 91-98.

${ }^{75}$ Remiro Brotóns (n 13) 127-129.

76 International Law Commission, 'Draft articles on Responsibility of States for Internationally Wrongful Acts, with commentaries, 2001' (2001) Yearbook of the International Law Commission 1, 112-113, art 40, [8 of the commentary to art 40].

${ }^{77}$ It is important to recall that, in current positive international law, not every human rights norm is peremptory. See: Antonio Gómez Robledo, El ius cogens internacional: Estudio histórico-crítico (Universidad Nacional Autónoma de México, 2003) 166-170; Human Rights Committee, General Comment No. 29, States of Emergency (Article 4), CCPR/C/21/Rev.1/Add.11 [2001], [11].

78 Human Rights Watch, World Report 2016 ch Serbia/Kosovo: Events of 2015 <https://www.hrw.org/world-report/2016/country-chapters/serbia/kosovo\#40e5f4> accessed 31 May 2016; Henry H Perritt, Jr., The Road to Independence for Kosovo: A Chronicle of the Ahtisaari Plan (CUP 2010) 241.
} 


\section{STATEHOOD AND INTERNATIONAL NORMS AS AN \\ OBSTACLE TO THE PROTECTION OF INTERNATIONAL COMMUNITY INTERESTS}

should permit or facilitate democratic and peaceful discussions about integrity or secession, while in turn independentist groups should not seek them arbitrarily or violently. States are historical constructions and many "national" groups are as well. It has been argued by international relations scholars that new State identities may be as artificial as allegedly historical nationalities, and that State creations are not automatically sources of unrest. ${ }^{79}$ Thus, refusal to grant independence is not necessarily either historical or arbitrary.

\section{CONCLUSIONS}

The globalized landscape curiously features dynamics and trends of hyper-localization and chauvinism, ${ }^{80}$ which sometimes generate discourses of independence. Such discourses are frequently more emotional than solidly grounded on international legal bases, but yet they seek to employ and appropriate an international legal language to further their aims. They do so firstly because law has an expressive function that may sometimes, provided that it is perceived as adequate and so demands obedience, ${ }^{81}$ legitimize or strengthen arguments, while stigmatizing contrary ones. Additionally, international law serves as a sort of semi-universal language in which demands and claims are presented. ${ }^{82}$

On top of this, law has certain ambiguity due to the role of effectiveness, which leads to formalizing what has been achieved in practice. Humanization and peremptory demands limit this criterion when it is evident that the success was achieved by means contrary to jus cogens, a reason why groups as ISIS or territorial gains by both State - e.g. Russia in Crimea - and non-state actors lack validity and everyone else is under an obligation to not recognize them nor to assist or contribute to them, given their erga omnes nature. Moreover, authors such as Lung-chu Chen argue that the humanization of international law must lead to supporting self-determination in the form of independence of peoples which cannot politically decide their destiny or make choices due to their being ignored or risk being oppressed, as may happen with Taiwan. ${ }^{83}$ This reminds us that law is far from perfect, and that sometimes it does not provide definite or perfect answers. Indeed, territorial integrity must be interpreted in light of humanity considerations: after all, law should exist for human beings.

Additionally, I argue that peremptory law also serves to declare independence when doing so is the only way to ensure the protection of

\footnotetext{
${ }^{79}$ Steven A. Cook and Amr T Leheta, 'Don't Blame Sykes-Picot for the Middle East's Mess' (Foreign Policy, 13 May 2016) <http://foreignpolicy.com/2016/05/13/sykes-picot-isntwhats-wrong-with-the-modern-middle-east-100-years/> accessed 31 May 2016.

${ }^{80}$ del Arenal (n 3) 38, 40, 51, 53, 60, 68-71.

${ }^{81}$ Koh (n 27) 2601.

${ }^{82}$ Klabbers (n 7) 16, 309, 315.

${ }^{83}$ Lung-chu Chen, 'The U.S.-Taiwan -China Relationship and the Evolution of Taiwan Statehood' (Opinio Juris, 16 May 2016) < http://opiniojuris.org/2016/05/16/the-u-s-taiwanchina-relationship-and-the-evolution-of-taiwan-statehood/> accessed 23 May 2016.
} 
peremptory human rights, and that third parties in that case must contribute by recognizing and ensuring that independence, granting it even if it is not effectively achieved. Perhaps this is what motivates those that recognize Palestine as a State in their bilateral relations or in the institutional fora of international organizations ${ }^{84}$ - curiously, such recognition may help to pave the way for the achievement of statehood, thus serving as a catalyst; and confirming that politics, as with so many international legal issues, is enmeshed with recognition.

Additional restrictions on abusive conduct and developments to humanize the role of territory in international law are needed, given how territory is sometimes invoked to block initiatives to protect victims and due to the destabilizing role of effectiveness and how it lures some to act boldly and the demand that international law responds to the real and social needs of the society it is meant to regulate: ${ }^{85}$ such society is not merely inter-State but global and transnational nowadays. This requires bearing in mind the needs of protecting human dignity, even from non-state abuses, when exploring territorial issues and the duties and rights of States to operate territorially and extraterritorially. If we fail to come up with additional restrictions on the risky notion of effectiveness and the paradoxes it generates we may be blamed for encouraging actions such as armed conflicts that are inhumane, insofar as armed conflicts always generate suffering and victims. That is why aggressor States and actors should be legally prevented from benefiting from the possibility of lawfully targeting enemy combatants and from benefiting from aggressive conduct, in light of the abuse de droit and Ex Injuria Jus Non Oritur principles. ${ }^{86}$

\footnotetext{
${ }^{84}$ Dapo Akande, 'Palestine as a UN Observer State: Does this Make Palestine a State?' (EJIL: Talk!, 3 December 2012) <http://www.ejiltalk.org/palestine-as-a-un-observer-statedoes-this-make-palestine-a-state/>; Andreas Zimmermann, 'Palestine at the Gates of the Peace Palace: The long and windy road towards Palestinian membership in the Permanent Court of Arbitration' (EJIL: Talk!, 5 April 2016) <http://www.ejiltalk.org/palestine-at-thegates-of-the-peace-palace-the-long-and-windy-road-towards-palestinian-membership-inthe-permanent-court-of-arbitration/>; Christiane Ahlborn, 'UNESCO Approves Palestinian Membership Bid - A Case for US Countermeasures Against the Organization?' (EJIL: Talk!, 8 November 2011) <http://www.ejiltalk.org/unesco-approves-palestinian-membership-bid--a-case-for-us-countermeasures-against-the-organization/> accessed 31 May 2016.

${ }^{85}$ Remiro Brotóns (n 13) 37.

${ }^{86}$ On this argument and the two cited principles, see: Nicolás Carrillo-Santarelli, 'A Humane Legal Response to Contemporary Challenges on the Use of Force posed by Non-State Threats and Possible Misuses of Military Necessity' (2016) 09 Quaestio Iuris 980, 987-990; Separate Opinion of Judge Ammoun to: International Court of Justice, Barcelona Traction, Light and Power Company, Limited, Judgment, I.C.J. Reports 1970 [7], [32]. Additionally, see the quote of H. Lauterpacht found in Michael Byers, 'Abuse of Rights: An Old Principle, A New Age’ (2002) 47 McGill Law Journal 389, 391, footnote 2; Separate Opinion of Judge Cançado Trindade to: Accordance with International Law of the Unilateral Declaration of Independence in Respect of Kosovo, Advisory Opinion, I.C.J. Reports 2010 [134]-[137]; International Court of Justice, Gabcikovo-Nagymaros Project (Hungary/Slovakia), Judgment, I.C.J. Reports 1997, p. 7 [133]; Oleksandr Merezhko, 'Crimea's Annexation by Russia - Contradictions of the New Russian Doctrine of International Law' (2015) 75 Zeitschrift für ausländisches öffentliches Recht und Völkerrecht/Heidelberg Journal of International Law 167, 186-187; Karl Zemanek, 'New Trends in the Enforcement of erga omnes Obligations' (2000) 4 Max Planck Yearbook of United Nations Law 1, 39-40.
} 


\section{References} 2002).

'Declaración de Autodeterminación, San Andrés, Islas' (28 April

Ahlborn C, 'UNESCO Approves Palestinian Membership Bid - A Case for US Countermeasures Against the Organization?' (EJIL: Talk!, 8 November 2011).

Akande D, 'Palestine as a UN Observer State: Does this Make Palestine a State?' (EJIL: Talk!, 3 December 2012).

Andorno R, 'Human Dignity and Human Rights as a Common Ground for a Global Bioethics' (2009) 34 Journal of Medicine and Philosophy 17.

Antonopoulos C, 'Force by Armed Groups as Armed Attack and the Broadening of Self-Defence' (2008) LV Netherlands International Law Review 159.

del Arenal C, 'La nueva sociedad mundial y las nuevas realidades internacionales: un reto para la teoría y para la política' in Cursos de Derecho Internacional y Relaciones Internacionales de Vitoria-Gasteiz 2001 (EHU 2002) 1.

d'Aspremont J, 'Non-State Actors in International Law: A Scholarly Invention?' (2009) FWO Seminar - Non-State Actors in International Law Leuven 26-28 March 20091.

Belanger-McMurdo A, 'A Fight for Statehood? ISIS and Its Quest for Political Domination' (E-International Relations Students, 5 October 2015).

Boyle J, 'Islamic State and the idea of statehood' (BBC News, 6 January 2015).

Byers M, 'Abuse of Rights: An Old Principle, A New Age' (2002) 47 McGill Law Journal 389.

Cançado Trindade A, 'Derecho Internacional de los Derechos Humanos, Derecho Internacional de los Refugiados y Derecho Internacional Humanitario: Aproximaciones y Convergencias' (1996) I Estudios Especializados de Derechos Humanos.

Carrillo-Santarelli N, 'Enhanced Multi--Level Protection of Human Dignity in a Globalized Context through Humanitarian Global Legal Goods' (2012) 13 German Law Journal 829.

— 'A Humane Legal Response to Contemporary Challenges on the Use of Force posed by Non-State Threats and Possible Misuses of Military Necessity' (2016) 09 Quaestio Iuris 980.

Cassese A, 'Remarks on Scelle's Theory of "Role Splitting" (dédoublement fonctionnel) in International Law' (1990) 1 EJIL 210.

— 'Ex iniuria ius oritur: Are We Moving towards International Legitimation of Forcible Humanitarian Countermeasures in the World Community?' (1999) 10 EJIL 23.

Chachko E and Deeks A, "Who is on Board with "Unwilling or Unable"? (Lawfare, 10 October 2016).

Chen L, 'The U.S.-Taiwan -China Relationship and the Evolution of Taiwan Statehood' (Opinio Juris, 16 May 2016).

Committee on Economic, Social and Cultural Rights, General comment No. 23 (2016) on the right to just and favourable conditions of work 
(article 7 of the International Covenant on Economic, Social and Cultural Rights), E/C.12/GC/23, 27 April 2016.

Committee on Economic, Social and Cultural Rights, General comment No. 22 (2016) on the right to sexual and reproductive health (article 12 of the International Covenant on Economic, Social and Cultural Rights), E/C.12/GC/22 [2016].

Committee on the Elimination of Discrimination against Women, General recommendation No. 34 (2016) on the rights of rural women, CEDAW/C/GC/34 [2016].

Concurring Opinion of Judge AA Cançado Trindade to: I/A Court H.R., Juridical Condition and Rights of the Undocumented Migrants. Advisory Opinion OC-18/03 of September 17, 2003. Series A No.18.

Concurring Opinion of Judge AA Cançado Trindade to: I/A Court H.R., Juridical Condition and Human Rights of the Child. Advisory Opinion OC-17/02 of August 28, 2002. Series A No.17.

Conference for Security and Cooperation in Europe, 1992 Summit, Helsinki, "The Challenges of Change", Helsinki Document 1992.

Cook S and Leheta A, 'Don't Blame Sykes-Picot for the Middle East's Mess' (Foreign Policy, 13 May 2016).

Cortés-Martín J, Las Organizaciones Internacionales: Codificación y Desarrollo Progresivo de su Responsabilidad Internacional (Instituto Andaluz de Administración Pública 2008).

Declaration of Judge Simma to: Accordance with International Law of the Unilateral Declaration of Independence in Respect of Kosovo, Advisory Opinion, I.C.J. Reports 2010.

Deva S and Bilchitz D, 'Response to Comments of Professor John Ruggie on "Human Rights Obligations of Business: Beyond the Corporate Responsibility to Respect?” (CUP 2013)' (15 January 2014) 1.

Domingo R, The New Global Law (CUP 2010).

Dupuy P, 'International Law: Torn between Coexistence, Cooperation and Globalization. General Conclusions' (1998) 9 EJIL 278.

Fitzmaurice M, 'Interpretation of Human Rights Treaties' in Dinah Shelton (ed), The Oxford Handbook of International Human Rights Law (OUP 2013).

Galindo Vélez F, 'Consideraciones sobre la determinación de la condición de refugiado' in Sandra Namihas (ed), Derecho Internacional de los Refugiados (Pontificia Universidad Católica del Perú 2001).

García-Pérez R, 'Recensión de: Pons Rafols, X., Cataluña: Derecho a decidir y Derecho internacional, Editorial Reus, Madrid, 2015.

Gatto A, 'Corporate Social Responsibility in the External Relations of the EU' (2005) 24 Yearbook of European Law 423.

Geisinger A and Stein M, 'A Theory of Expressive International Law' (2007) 60 Vanderbilt Law Review 77.

Gómez Robledo A, El ius cogens internacional: Estudio históricocrítico (Universidad Nacional Autónoma de México, 2003).

Heller K, "The Seemingly Inexorable March of "Unwilling or Unable" Through the Academy' (Opinio Juris, 6 March 2015).

Juris, 11 October 2015). 
Henckaerts J, 'Customary International Humanitarian Law: a response to US comments' (2007) 89 Intl Rev of the Red Cross 473.

Henderson C, 'The Extraterritorial Seizure of Individuals under International Law - The Case of al-Liby: Part II' (EJIL: Talk!, 7 November 2013).

Human Rights Committee, General Comment No. 29, States of Emergency (Article 4), CCPR/C/21/Rev.1/Add.11 [2001].

\section{CCPR/C/UNK/CO/1 [2006].}

Observations on Kosovo (Serbia),

Human Rights Council, Report on the first session of the open-ended intergovernmental working group on transnational corporations and other business enterprises with respect to human rights, with the mandate of elaborating an international legally binding instrument [2016] $\mathrm{A} / \mathrm{HRC} / 31 / 50$

Human Rights Council, Report on the first session of the open-ended intergovernmental working group on transnational corporations and other business enterprises with respect to human rights, with the mandate of elaborating an international legally binding instrument, Chair-Rapporteur: María Fernanda Espinosa, A/HRC/31/50 [2016].

I/A Court H.R., "Other treaties" subject to the consultative jurisdiction of the Court (Art. 64 American Convention on Human Rights). Advisory Opinion OC-1/82 of September 24, 1982. Series A No. 1.

Case of Velásquez Rodríguez v Honduras. Merits. Judgment of July 29, 1988. Series C No. 4.

- The Right to Information on Consular Assistance in the Framework of the Guarantees of the due Process of Law. Advisory Opinion OC-16/99 of October 1, 1999. Series A No.16.

Inter-American Commission on Human Rights, Indigenous Peoples, Afro-Descendent Communities, and Natural Resources: Human Rights Protection in the Context of Extraction, Exploitation, and Development Activities (also known as 'Indigenous Peoples, Communities of African Descent, Extractive Industries), OEA/Ser.L/V/II, Doc. 47/15 [2015]. $20 / 15$ [2015].

- Towards the Closure of Guantanamo, OAS/Ser.L/V/II, Doc.

International Court of Justice, Corfu Channel case, Judgment of April 9th, 1949: I.C.J. Reports 1949.

_ Gabcikovo-Nagymaros Project (Hungary/Slovakia), Judgment, I.C.J. Reports 1997.

L Legal Consequences of the Construction of a Wall in the Occupied Palestinian Territory, Advisory Opinion, I.C.J. Reports 2004.

- Accordance with International Law of the Unilateral Declaration of Independence in Respect of Kosovo, Advisory Opinion, I.C.J. Reports 2010.

International Law Commission, 'Draft articles on Responsibility of States for Internationally Wrongful Acts, with commentaries, 2001' (2001) Yearbook of the International Law Commission

International Law Commission, Identification of customary international law: Text of the draft conclusions provisionally adopted by the Drafting Committee [2015] A/CN.4/L.869. 
Kaul I and Mendonza R, 'Advancing the Concept of Public Goods' in Inge Kaul et al. (eds) Providing Global Public Goods (OUP 2003).

Kaul I, Conceiçao P, Le Goulven K and Mendoza R, 'How to Improve the Provision of Global Public Goods' in Inge Kaul et al. (eds) Providing Global Public Goods (OUP 2003).

Kittrie O, Lawfare: Law as a Weapon of War (OUP 2016) 1-5; Orde F. Kittrie, 'The emergence of lawfare [infographic]' (OUPblog, 16 May 2016).

Klabbers J, International Law (CUP 2013).

Koh H, 'Why Do Nations Obey International Law?' (1997) 106 The Yale Law Journal 2599.

Lang A, 'Legal basis for UK military action in Syria' (2015) 7404 United Kingdom House of Commons Library Briefing Papers 1.

Lee T, 'International Law, International Relations Theory, and Preemptive War: The Vitality of Sovereign Equality Today' (2004) 67 Law and Contemporary Problems 147.

Maastricht Principles on Extraterritorial Obligations of States in the Area of Economic, Social and Cultural Rights.

McAdams R, The Expressive Powers of Law: Theories and Limits (Harvard UP 2015) 1-10.

McDougal $\mathrm{M}$ and Lasswell $\mathrm{H}$, 'The Identification and Appraisal of Diverse Systems of Public Order' (1959) 53 AJIL 1.

Merezhko O, 'Crimea's Annexation by Russia - Contradictions of the New Russian Doctrine of International Law' (2015) 75 Zeitschrift für ausländisches öffentliches Recht und Völkerrecht/Heidelberg Journal of International Law 167.

Meron T, The Humanization of International Law (Martinus Nijhoff 2006).

Milanovic M, 'Self-Defense and Non-State Actors: Indeterminacy and the Jus ad Bellum' (EJIL: Talk!, 21 February 2010). 2011). 'Al-Skeini and Al-Jedda in Strasbourg' (EJIL: Talk!, 29 August 'Extraterritorial Application of Human Rights Treaties: An Overview' (EJIL: Talk!, 30 November 2011).

'A Few Thoughts on Hassan v United Kingdom' (EJIL: Talk!, 22 October 2014)

— 'Jurisdiction, Attribution and Responsibility in Jaloud' (EJIL: Talk!, 11 December 2014).

Montevideo Convention on the Rights and Duties of the States.

Nijman J, 'Non-state actors and the international rule of law: Revisiting the 'realist theory' of international legal personality' (2010) Amsterdam Center for International Law Research Paper Series 1.

Oduntan G, Sovereignty and Jurisdiction in the Airspace and Outer Space: Legal Criteria for Spatial Delimitation (Routledge 2012) 132; John Kish, International Law and Espionage (Martinus Nijhoff 1995).

Ohlin J, 'The Unwilling or Unable Doctrine Comes to Life' (Opinio Juris, 23 September 2014).

Perritt H, The Road to Independence for Kosovo: A Chronicle of the Ahtisaari Plan (CUP 2010). 
Pinto M, 'El principio pro homine. Criterios de hermenéutica y pautas para la regulación de los derechos humanos' in Martín Abregú and Christian Courtis (eds), La aplicación de los tratados sobre derechos humanos por los tribunales locales (Centro de Estudios Legales y Sociales 1997).

Pitts J, 'Intervention and sovereign equality: legacies of Vattel' in Stefano Recchia and Jennifer M. Welsh (eds), Just and Unjust Military Intervention: European Thinkers from Vitoria to Mill (CUP 2013).

Posner E, The Twilight of Human Rights Law (OUP 2014).

Protocol Additional to the Geneva Conventions of 12 August 1949 and relating to the Protection of Victims of International Armed Conflicts (Protocol I).

Protocol Additional to the Geneva Conventions of 12 August 1949, and relating to the Protection of Victims of Non-International Armed Conflicts (Protocol II).

Ratner S, The Thin Justice of International Law: A Moral Reckoning of the Law of Nations (OUP 2015).

Remiro Brotóns A et al., Derecho Internacional: Curso General (Tirant Lo Blanch 2010).

Reports of International Arbitral Awards, Vol II, Island of Palmas case (Netherlands, USA) 4 April 19.

Rosalyn Higgins, Problems \& Process: International Law and How We Use it (OUP 2004). 25506.

SC of Canada [1998] Reference re Secession of Quebec File No.:

Separate Opinion of Judge Ammoun to: International Court of Justice, Barcelona Traction, Light and Power Company, Limited, Judgment, I.C.J. Reports 1970.

Separate Opinion of Judge Cançado Trindade to: Accordance with International Law of the Unilateral Declaration of Independence in Respect of Kosovo, Advisory Opinion, I.C.J. Reports 2010.

Separate Opinion of Judge Cançado Trindade to: Accordance with International Law of the Unilateral Declaration of Independence in Respect of Kosovo, Advisory Opinion, I.C.J. Reports 2010.

Separate Opinion of Judge Kooijmans to: International Court of Justice, Armed Activities on the Territory of the Congo (Democratic Republic of the Congo v Uganda), Judgment, I.C.J. Reports 2005.

Shany Y, Cohen A and Mimran T, 'ISIS: Is the Islamic State Really a State?' (The Israel Democracy Institute, 14 September 2014).

Sloan J, 'Breaching international law to ensure its enforcement: the reliance by the ICTY on illegal capture' (2003) 6 Yearbook of International Humanitarian Law 319.

de Than A and Shorts E, International Criminal Law and Human Rights (Sweet \& Maxwell 2003).

Thürer D, 'The Emergence of Non-Governmental Organizations and Transnational Enterprises in International Law and the Changing Role of the State' in Rainer Hofmann (ed), Non-State Actors as New Subjects of International Law (Duncker \& Humblot 1999).

United Nations General Assembly Resolution 1514 (XV) [1960]. 
United Nations General Assembly Resolution 2625 (XXV) [1970].

United Nations, A more secure world: Our shared responsibility, Report of the High-level Panel on Threats, Challenges and Change [2004].

United Nations, Guiding Principles on Business and Human Rights: Implementing the United Nations "Protect, Respect and Remedy Framework" [2011].

Van Staden A and Vollaard H, 'The Erosion of State Sovereignty: Towards a Post-territorial World?' in Gerard Kreijen et al (eds), State, Sovereignty, and International Governance (OUP 2002).

de Vattel E, The Law of Nations, Or, Principles of the Law of Nature, Applied to the Conduct and Affairs of Nations and Sovereigns, with Three Early Essays on the Origin and Nature of Natural Law and on Luxury (LF ed 1797).

Vienna Convention on the Law of Treaties.

Villalpando S, 'The Legal Dimension of the International Community: How Community Interests Are Protected in International Law' (2010) 21 EJIL 387.

Waisberg T, 'Colombia's Use of Force in Ecuador Against a Terrorist Organization: International Law and the Use of Force Against Non-State Actors' (2008) 12 ASIL Insights.

Wallace S, 'Refining Al-Skeini v UK: The ECtHR's Grand Chamber hearing in Jaloud v Netherlands' (EJIL: Talk!, 7 March 2014).

Zemanek K, 'New Trends in the Enforcement of erga omnes Obligations' (2000) 4 Max Planck Yearbook of United Nations Law 1.

Zimmermann A, 'Palestine at the Gates of the Peace Palace: The long and windy road towards Palestinian membership in the Permanent Court of Arbitration' (EJIL: Talk!, 5 April 2016). 